\title{
POŠTA
}

TELEKOMUNIKÁCIE A

ELEKTRONICKY OBCHOD

\section{HODNOTENIE WEB DIZAJNU ELEKTRONICKÉHO OBCHODU}

\author{
Jakub Cíba*
}

\section{1. Úvod}

Príspevok predstavuje spracovanie efektov elektronického obchodovania $\mathrm{v}$ podmienkach vybraného obchodného podniku, konkrétne spoločnosti Vallens s.r.o. so sídlom v Žiline. Spoločnost' prevádzkuje svoj elektronický obchod CistySvet.SK od roku 2008 a pôsobí ako autorizovaný dovozca cyklónových vysávačov Dyson, čističov a zvlhčovačov vzduchu Bionaire a sušičiek ovocia a zeleniny Hydraflow.

\section{Hodnotenie web dizajnu}

V dnešnej dobe, ked’ je zákazník zaplavený web stránkami, je dôležité, aby bola stránka svojim spôsobom výnimočná, intuitívne spracovaná a hlavne, aby zákazníka upútala. Z týchto dôvodov je dôležité neustále pracovat' na dizajne, použitel'nosti a hlavne na funkčnosti stránky. Zároveň je nutné dodržiavat' webové konvencie, pretože zákazník si už predošlých skúseností vytvoril určitú mentálnu mapu t.j. ako by mal daný systém klasifikácie a navigácie vyzerat'. Priority pre tvorbu web stránky sa môžu medzi jednotlivými spoločnost'ami líšit', avšak medzi hlavné ciele a úlohy prežitia webovej stránky je budovanie dlhodobého vzt’ahu so zákazníkmi, ktorý obsahuje tieto kroky:

- získanie zákazníkov - návštevník stránky sa premení na zákazníka;

- udržanie zákazníkov - zabezpečenie opakovaných nákupov;

- zvýšenie predaja (cross - selling) - zákazníci nakupujú aj ostatné ponúkané produkty.

Pre dosiahnutie uvedených ciel'ov, musia byt' dosiahnuté nasledujúce kritéria:

- vysoko kvalitný obsah (,,content is king“) - spoločnost' musí mat' správne informácie na správnom mieste a $\mathrm{v}$ pravý čas;

- jednoduché použitie - jednoduchá, jasná a l’ahko používajúca navigácia ul’ahčujúca používanie web stránky;

- rýchle otváranie a st’ahovanie informácií na stránke - návštevníci neradi čakajú na informácie;

- pravidelná aktualizácia - pravidelné aktualizovanie obsahu web stránky.

Hodnotenie web dizajnu internetového obchodu CistySvet.SK bude obsahovat' zhodnotenie z hl'adiska farebnosti, estetiky a funkčnosti. Web stránka je znázornená na Obrázku 1.

\footnotetext{
* Ing. Jakub Cíba, Žilinská univerzita v Žiline, Fakulta Prevádzky a ekonomiky dopravy a spojov, Katedra spojov, Univerzitná 1, 01026 Žilina, tel. č.: 041/513 3144, e-mail: jakub.ciba@fpedas.uniza.sk
} 


\subsection{Hl'adisko farebnosti a estetiky}

Výber farebnej schémy web stránky je jednou z najt’ažších fáz navrhovania dizajnu. Základom pre dosiahnutie žiadaného efektu je dobre vytvorená stránka. Môžeme tu zaradit' najmä ladiace a dobre zvolené farby.

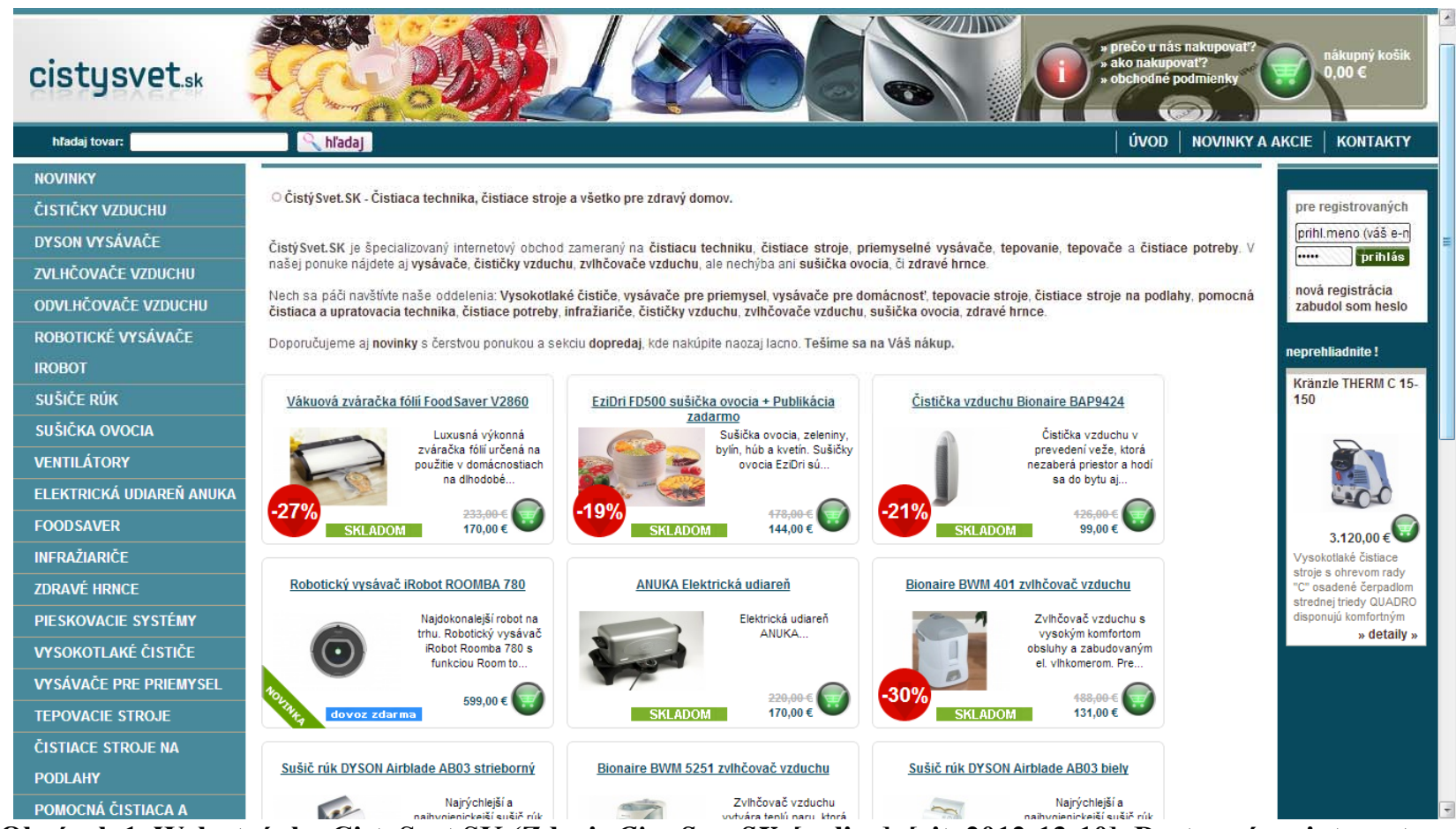

Obrázok 1. Web stránka CistySvet.SK (Zdroj: CistySvet.SK. [online]. [cit. 2012-13-10]. Dostupné na internete: $<$ http://cistysvet.sk/>.)

Ústrednou farbou stránky CistySvet.SK je modrá, ktorá prevláda nielen na celej webovej stránke, ale aj v logu. Modrá farba pôsobí ako farba, ktorá u l'udí z hl'adiska psychológie farieb evokuje hlavne pokoj, vyrovnanost', vernost', dôveru, tradíciu a istotu. Celkové zladenie farebnosti na stránke je ukl'udňujúce a predstavuje istotu, dôveru, spol'ahlivost' a priatel'stvo. $\mathrm{V}$ dnešnej dobe je vel'mi dôležité vystupovat' u návštevníkov a zákazníkov webovej stránky týmto spôsobom, vzhl'adom na obor podnikania. Tento dizajn pôsobí na l'udí ukl'udňujúco a zároveň ich uist'uje o spol'ahlivosti spoločnosti. Farba písma a podkladu na web stránke musí byt' dostatočné kontrastná, aby sa text dal l'ahko identifikovat' a prečítat'. Celkový text na stránke spĺn̆a štandardy pre kontrast a je čitatel'ný v každej časti. Celá stránka je esteticky zladená a farebnost' je vel'mi vhodné zvolená, vd’aka čomu môže návštevníka ihned' upútat', a to ešte predtým, ako získal samotnú hl'adanú informáciu. $\mathrm{Na}$ stránke sa nenachádza ani príliš vel'a grafiky, ktorá môže spôsobit' spomal'ované načítanie stránky, tak isto stránka neobsahuje ani príliš vel’a textu, ktorý nezaujme.

Web stránka spĺn̆a aj hlavné prvky, ktoré tvoria základné rozvrhnutie (layout):

- logo sa nachádza v l'avom hornom rohu;

- hlavné menu (top menu) sa nachádza na l'avej časti stránky, ktoré slúži pre základnú navigáciu;

- päta stránky (spodná čast') obsahuje informácie o autorstve, identifikáciu tvorcov a monitorovanie návštevnosti stránky. 


\subsection{Navigácia na stránke}

V rámci analýzy prijatel'nosti používatel'ského rozhrania na webovej stránke sme posudzovali jednotlivé časti navigácie osobitne.

Horná čast' navigácie (pozri Obrázok 2.) obsahuje nasledovné:

- $\operatorname{logo}$ - po kliknutí na logo sa zákazník dostane na úvodnú stránku, vel'ké množstvo web stránok má na svojich stránkach logo, ale neprelinkujú ho s úvodnou stránkou;

- interaktívne vyhl'adávanie;

- prečo u nás nakupovat?;

- ako nakupovat?;

- obchodné podmienky;

- kontakty;

- nákupný košík;

- úvod;

- novinky a akcie;

- dopredaj;

- partneri.

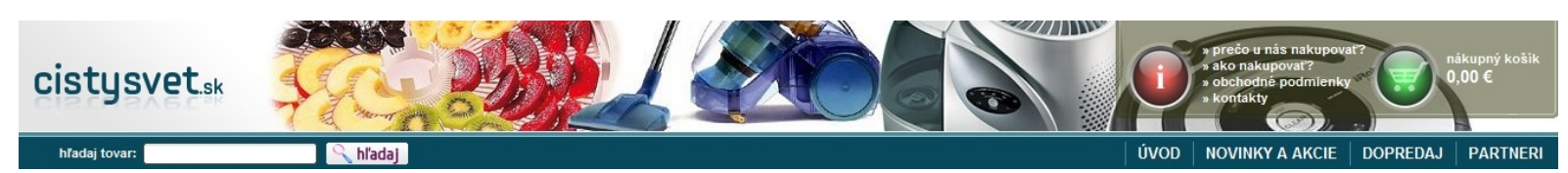

Obrázok 2. Horná čast' navigácie (Zdroj: CistySvet.SK. [online]. [cit. 2012-13-10]. Dostupné na internete: $<$ http://cistysvet.sk/>.)

Lavá čast' navigácie (pozri Obrázok 3.) obsahuje produktové portfólio, ktoré nie je dynamické, ale je zobrazené na každej stránke rovnako. Vel'a webových tvorcov používa dynamické menu v dobrej viere, ale opak je pravdou. S dynamickým menu je nútený zákazník porovnávat' naraz 7 krát viac variant, než zodpovedá jeho schopnostiam, čo môže spôsobit' frustráciu používatel'ov, zmätenie, stratenie sa na webe alebo rovno odchod z web stránky.

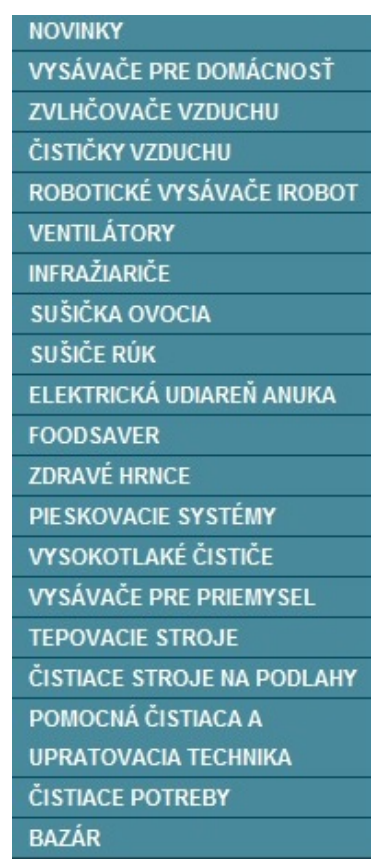

Obrázok 3. Lavá čast' navigácie (Zdroj: CistySvet.SK. [online]. [cit. 2012-13-10]. Dostupné na internete: $<$ http://cistysvet.sk/>.) 
V pravej časti navigácie (pozri Obrázok 4.) sa nachádza prihlásenie/registrácia a náhodne vybraný produkt z ponuky, ktorý sa mení pri každej vykonanej akcie na stránke.

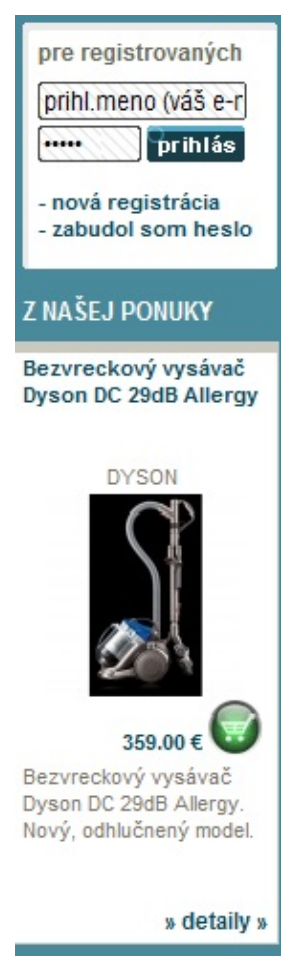

Obrázok 4. Pravá čast' navigácie (Zdroj: CistySvet.SK. [online]. [cit. 2012-13-10]. Dostupné na internete: $<$ http://cistysvet.sk/>.)

Spodná čast' navigácie je opät' zobrazená na každej stránke a sú tu odkazy na informácie o autorstve, identifikáciu tvorcov a monitorovanie návštevnosti stránky. Ako nevýhodu by som uviedol, že tu chýba mapa stránok, ktorá slúži pre lepšiu navigáciu na stránke. Celkovú navigáciu na stránke možno hodnotit' kladne. Jednotlivé prvky sú na intuitívne a majú svoje logické usporiadanie, tým pádom by nemal mat' návštevník žiadne problémy pri nájdení produktu, či iných nájdení iných dôležitých informácií.

\subsection{Funkčné hl'adisko}

Web stránka zahrňuje nasledovné funkcie:

\section{Funkcia 1. Nákupný košík}

- jeho stav sa zobrazuje v pravom hornom rohu a na každej zobrazenej stránke;

- obsah si možno kedykol'vek zobrazit' kliknutím na ikonu košíka;

- položky z košíka sa dajú vymazat' pomocou tlačidla vymazat';

- ak si zákazník zmení množstvo kusov tovaru v košíku, stačí kliknút’ na tlačidlo prepočítat' a systém zaktualizuje celkovú sumu nákupu;

- objednaním produktov, zákazník získava bonus na d’alší nákup.

\section{Funkcia 2. Interaktívne hl'adanie}

- ide o vyhl'adávanie produktov, v prípade, že zadanému kritériu nevyhovuje žiadny produkt, systém ponúkne produkt, ktorý je najbližšie požadovanému produktu;

- zmena vo filtri sa okamžite prejaví v ponuke produktov. 


\section{Funkcia 3. Porovnávanie produktov}

- pri každom produkte sú poskytnuté podrobné informácie s prehl'adným zobrazením jednotlivých parametrov, či prevedenia pre každý ponúkaný produkt;

- vd’aka tomu sa dá použit' funkcia porovnávanie, pomocou ktorej si zákazník môže prehl'adne zobrazit' viac produktov vedl'a seba.

Funkcia 4. Registrácia

- riešenie je vel'mi jednoduché, stačí vyplnit' prihlasovacie, kontaktné údaje a dodaciu a fakturačnú adresu.

Funkcia 5. Opýtanie sa predajcu

Funkcia 6. Ponuka noviniek a akcií

Funkcia 7. Dopredaj

Funkcie, ktoré webová stránka ponúka sú vel'mi užitočné, prehl'adne spracované a intuitívne. Ale aj napriek tomu je stále čo zlepšovat'. Chýba tu napríklad ponuka najpredávanejších a najvyhl'adávanejších produktov, možnost' hodnotenia produktov návštevníkmi (diskusia) a absencia viacjazyčnej podpory.

\section{Celkové zhodnotenie}

CistySvet.SK dominuje hlavne svojím stvárnením, funkciami, ktoré sú nápomocné pri vyberaní produktov a obsahom. Je potrebné zdôraznit' možnost' interaktívneho vyhl'adávania a prepracovaného dizajnu, ako aj porovnávanie jednotlivých produktov podla parametrov. Ďalšou výhodou web stránky je aj validita znázornená na Obrázku 5.. Validita web stránky hovorí o tom, že webová stránka bola vytvorená podl'a štandardov konzorcia W3C (World Wide Web Consortium). Ak je web stránka valídna, tak je zaručené, že sa v nich vyhl'adávač (robot alebo spider), ktorý indexuje obsah web stránky, nestratí. Valídna stránka sa rýchlejšie načítava (rýchlejšie sa zobrazí v okne prehliadača www stránok). Ďalšou zárukou validného kódu je aj jej správne zobrazenie vo viacerých prehliadačoch webových stránok. Medzi určitú výhodu môžeme zaradit' aj prístupnost' stránky, čo znamená, že stránky sú prístupné taktiež na zariadeniach bez klasického monitora - mobil, pda, tablet (pozri Obrázok 6.).

\section{W3 $C^{\circ}$ Markup Validation Service}

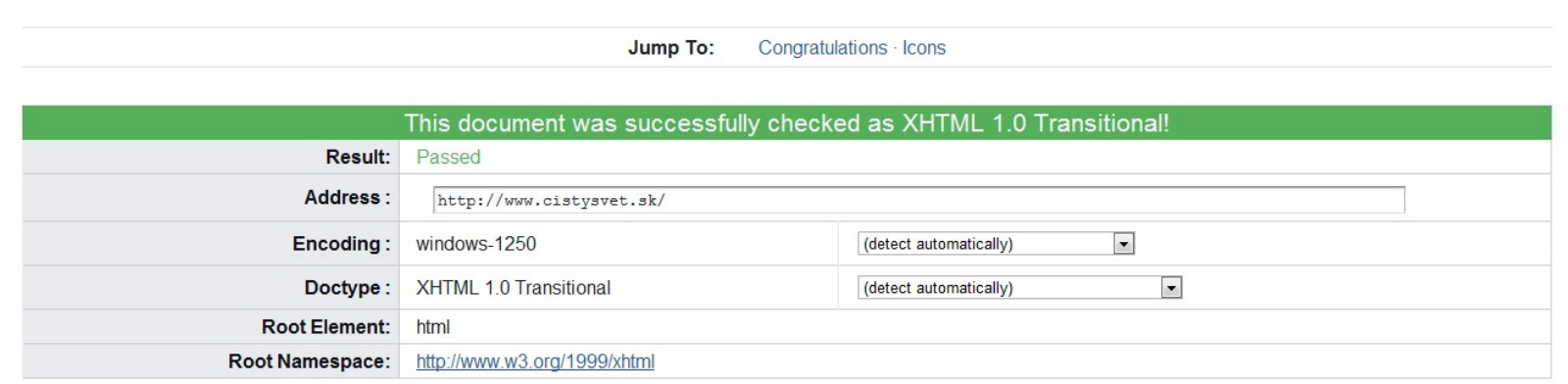

Obrázok 5. Validita web stránky (Zdroj: W3C. [online]. [cit. 2012-13-10]. Dostupné na internete: $<$ http://validator.w3.org/check?uri=http\%3A\%2F\%2Fwww.cistysvet.sk\%2F\&charset=\%28detect+autom atically $\% 29 \&$ doctype $=$ Inline \&group $=0 />$.) 


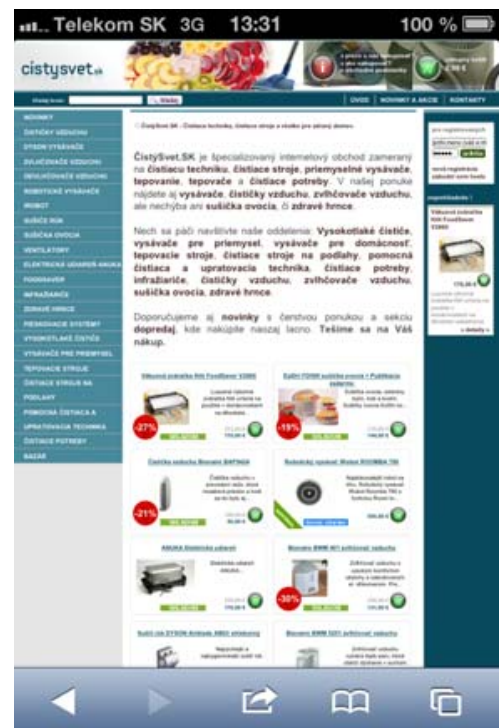

Obrázok 6. Stránka zobrazená na smartphone (Zdroj: CistySvet.SK. [online]. [cit. 2012-13-10]. Dostupné na internete: <http://cistysvet.sk/>.)

Samozrejmost’ou je, že táto stránka má aj nedostatky, ako napríklad absencia viacjazyčnej podpory, ponuka najpredávanejších a najvyhl'adávanejších produktov, alebo diskusia ku každému produktu.

\begin{tabular}{|c|c|c|c|c|}
\hline & Kritéria hodnotenia & $\begin{array}{c}\text { Váha } \\
\left(\mathbf{w}_{\mathrm{i}}\right) \\
{[1-0]}\end{array}$ & $\begin{array}{c}\text { Stupeň splnenia } \\
\text { kritéria }\left(\mathbf{x}_{\mathbf{i}}\right) \\
{[\mathbf{0 , 1 , 2 ]}}\end{array}$ & $\begin{array}{c}\mathbf{W}_{\mathbf{i}} \cdot \\
\mathbf{x}_{\mathbf{i}}\end{array}$ \\
\hline 1 & Logo a poslanie serveru & 1,0 & 2 & 2,0 \\
\hline 2 & $\begin{array}{l}\text { Prehl'adná hierarchia serveru } \\
\text { Navigácia musí byt' zrozumitel'ná a konzistentná na } \\
\text { všetkých častiach web stránky. } \\
\text { Každá čast' web stránky v rámci sekcií musí obsahovat' } \\
\text { odkaz na vyššiu úroveň v hierarchií web stránok a odkaz na } \\
\text { úvodnú stránku. }\end{array}$ & 1,0 & 2 & 2,0 \\
\hline 3 & $\begin{array}{l}\text { Vyhl'adávanie } \\
\text { Ak je stránka dátovo objemnejšia mala by mat' okrem } \\
\text { klasickej navigácia (v zmysle hlavného menu) k dispozícií } \\
\text { aj možnost' vyhl'adávania či odkaz na mapu webovej } \\
\text { stránky. }\end{array}$ & 1,0 & 1 & 1,0 \\
\hline 4 & Prítomnost' nákupného košíka & 0,7 & 2 & 1,4 \\
\hline 5 & $\begin{array}{l}\text { Výsledná cena zahrňujúca cenu aj s DPH, dopravu } \\
\text { a pod. } \\
\text { Ide o kompletnú cenu. Je možné, že cena za doručenie je } \\
\text { súčast'ou cenovej kalkulácie. }\end{array}$ & 0,7 & 2 & 1,4 \\
\hline 6 & Možnost' odstránenia produktu z košíka & 0,7 & 2 & 1,4 \\
\hline 7 & Možnosti výberu spôsobu platby & 0,5 & 2 & 1,0 \\
\hline 8 & Dostatočné množstvo informácií o produktoch & 0,5 & 2 & 1,0 \\
\hline 9 & Dostatočné množstvo obrázkov produktov & 0,5 & 2 & 1,0 \\
\hline 10 & Dostatočné možnosti výberu doručenia & 0,3 & 2 & 0,6 \\
\hline 11 & $\begin{array}{l}\text { Rýchle vyhl'adanie obchodných, reklamačných } \\
\text { a dodacích podmienok }\end{array}$ & 0,3 & 2 & 0,6 \\
\hline 12 & Verzia stránky vo viacerých jazykoch & 0,3 & 0 & $\mathbf{0 , 0}$ \\
\hline 13 & Psychológia farieb & 0,1 & 2 & 0,2 \\
\hline 14 & Registrácia & 0,1 & 2 & 0,2 \\
\hline 15 & Prvky dôveryhodnosti stránky & 0,1 & 2 & 0,2 \\
\hline SPOLU & & & & 14 \\
\hline
\end{tabular}

Tabul'ka 1. Hodnotenie vybraných kritérií internetovej stránky (zdroj: autor) 
Celkové hodnotenie stránky (pozri Tabul'ka 1.) predstavuje hodnotu $14 \mathrm{z}$ celkovej hodnoty 15,6 . Z tohto výsledku sa dá usúdit', že ide o web stránku, ktorá spíňa požiadavky vel'kého počtu zákazníkov. Ako webová stránka je pre bežných používatel'ov CistySvet.SK výborná, informácie sú usporiadané prehl'adne a zrozumitel’ne. Pre používatel'ov s určitým zdravotným obmedzením je použitie pravdepodobne náročnejšie. Jedná sa najmä o zákazníkov s poruchami zraku.

Analýza sily webu CistySvet.SK bola vypracovaná internetovým portálom SEO-servis a celková sila webu bola vypočítaná na $96 \%$. V Tabul'ke 2. je možné vidiet' hodnotenie stránky z rôznych hl'adísk.

\begin{tabular}{|l|c|}
\hline \multicolumn{1}{|c|}{ SEO servis } & $\mathbf{9 6 \%}$ \\
\hline Pagerank (GooglePagerank) & $4 / 10$ \\
\hline Srank (SeznamPagerank) & $1 / 10$ \\
\hline $\begin{array}{l}\text { Pozícia na Google po zadaní prvých 4 slov } \\
\text { titulku: 1. }\end{array}$ & $10 / 10$ \\
\hline $\begin{array}{l}\text { Pozícia na Sezname po zadaní prvých 4 slov } \\
\text { titulku: 1. }\end{array}$ & $10 / 10$ \\
\hline Popularita URL adresy & $8 / 10(30500)$ \\
\hline Spätné odkazy a obsah internetu & $7 / 10(12657)$ \\
\hline Indexované stránky & $5 / 10(1760)$ \\
\hline Staroba domény & $10 / 10(1574$ dní) \\
\hline
\end{tabular}

Tabul'ka 2. Úspešnost' webovej stránky www.cistysvet.sk (Zdroj: autor)

V Tabul'ke 2 sa nachádzajú vybrané faktory hodnotenia kvality webových stránok. PageRank patrí medzi základné faktory na hodnotenie kvality webovej stránky. PageRank je generovaný najpoužívanejším vyhl'adávačom na svete: Google-om. Čím väčší rank, tým väčšia šanca, že sa práve stránka objaví na prvých miestach v Google vyhl'adávači. Srank je rank na hodnotenie kvality webovej stránky od českého vyhl'adávača - Seznam.cz. V Čechách sa používa Seznam.cz na vyhl'adávanie častejšie ako Google a preto pre majitel'ov stránok zameraných na Český jazyk je vysoký Srank určite vel'kým plus. Pozícia na Google a na Sezname predstavuje umiestnenie webovej stránky na Google a Sezname po zadaní prvých 4 slov titulku. Popularita URL adresy je počet výskytov URL adresy stránky medzi webovými stránkami z iných domén. Spätné odkazy a obsah internetu je počet spätných odkazov vedúcich na testovanú doménu. Indexované stránky predstavujú počet zaindexovaných stránok na doméne vyhl'adávača Google. Staroba domény sa určuje podl'a prvého zaindexovania do webarchívu. Staršie domény predstavujú väčšiu autoritu.

Tabul'ky 1. a 2. predstavujú určitý prístup k hodnoteniu webovej stránky, pričom je možné konštatovat', že webová stránka CistySvet.SK splńa dôležité kvalitatívne predpoklady, čo sa následne prejavuje u zákazníkov v súvislosti s naplnením ich požiadaviek. 


\section{Literatúra}

[1] CÍBA, J.: Efekty elektronického obchodovania v podmienkach vybraného obchodného podniku: diplomová práca. Žilina: 2012, 94s.

[2] MADLEŇÁK, R. Elektronický obchod. Žilina: EDIS, 2004. 162 s. ISBN 80-8070-192-X.

[3] Interné materiály Vallens, s.r.o., 2012

[4] CistySvet.SK [online]. [cit. 2012-13-10]. Dostupné na internete: $<$ http://www.cistysvet.sk/ $>$.

[5] W3C. [online]. [cit. 2012-13-10]. Dostupné na internete: < http://validator.w3.org/> 